\title{
Manajemen Bandwidth Menggunakan Metode Hierarchical Token Bucket (HTB) di Farid.net
}

\author{
Bandwidth Management Hierarchical Token Bucket (HTB) Method in \\ Farid.Net
}

\author{
Lukman*1, Arif Marda Saputro $^{2}$, Andi Satrio Wicaksono ${ }^{3}$, \\ Farid Hakim Tri Hartomo ${ }^{4}$, Muhammad Nugraha Jatun ${ }^{5}$ \\ 1,2,3,4,5 Fakultas Ilmu Komputer, Universitas AMIKOM Yogyakarta \\ E-mail: *1'masman@amikom.ac.id, ${ }^{2}$ arif.0004@students.amikom.ac.id, \\ ${ }^{3}$ andi.wicaksono@ students.amikom.ac.id, ${ }^{4}$ farid.h@students.amikom.ac.id, \\ ${ }^{5}$ muhammad.jatun@students.amikom.ac.id
}

\begin{abstract}
Abstrak
Pada masa modern seperti ini kebutuhan akan internet semakin meningkat tajam, baik itu untuk bekerja mengolah data dan hiburan. Untuk membangun infrastruktur jaringan yang baik tentunya dibutuhkan penanganan yang tepat sesuai dengan kondisi di lapangan. Dalam penelitian ini kami mengangkat tema penerapan metode HTB yang akan diimplementasikan dalam jaringan RT/RW Net di Farid.net. Dalam analisa jaringan ini terdapat suatu masalah, setelah pengelompokan data dari pelanggan dimana terdapat keluhan tentang bandwidth yang didapat tidak sesuai dengan paket yang dipilih, sehingga hal tersebut menimbulkan ketidaknyamanan pengguna. Untuk mengatasi masalah tersebut kami mendapatkan solusi dengan menerapkan metode HTB. Cara kerja dari metode ini sendiri, membagi bandwidth kedalam beberapa kelas, yang mana terdapat dua kelas utama yaitu parent dan child, metode ini memungkinkan administrator untuk membagi bandwidth berdasarkan besar bandwidth yang diminta pelanggan. Dari penerapan metode HTB dapat diambil kesimpulan bahwa bandwidth yang didapat antar user menjadi lebih stabil dan merata, hal tersebut dapat dibuktikan dengan melalui Speedtest dan pemantauan traffic. Selain itu konektivitas jaringan pun juga lebih stabil dikarenakan bandwidth dari client sudah terkontrol.
\end{abstract}

Kata Kunci-bandwidth, Hierarchical Token bandwidth, HTB.

\begin{abstract}
In modern times like this the need for the internet is increasing sharply, both for working on data processing and entertainment. To build a good network infrastructure, of course, proper handling is needed according to the conditions in the field. In this study we raise the theme of applying the HTB method which will be implemented in the RT / RW Net network at Farid.net. In this network analysis there is a problem, after grouping data from customers where there are complaints about the bandwidth obtained that is not in accordance with the package chosen, so that it causes user inconvenience. To overcome this problem, we got a solution by applying the HTB method. The workings of this method itself, dividing bandwidth into several classes, where there are two main classes, namely parent and child, this method allows the administrator to divide the bandwidth based on the bandwidth requested by the customer. From the application of the HTB method, it can be concluded that the bandwidth obtained between users becomes more stable and equitable, this can be proven by Speedtest and traffic monitoring. In addition, network connectivity is also more stable because the bandwidth of the client is controlled.
\end{abstract}

Keywords - bandwidth, Hierarchical Token bandwidth, HTB. 


\section{PENDAHULUAN}

Farid.net merupakan usaha yang bergerak dalam bidang penyedia layanan internet di Kec. Jumantono, Kab. Karanganyar, Jawa Tengah. Farid.net merupakan layanan peyedia bandwidth / internet yang menyasar pasar utamanya adalah warga lingkungan sekitar. Berbeda dengan ISP yang cakupan jaringan / areanya besar, farid.net ini adalah penyedia layanan internet berbasis sistem RT/RW Net yang mana pemasok bandwidthnya tetap dari ISP, bisa dikatakan kalau farid.net merupakan reseller dari ISP yang memiliki 8 client aktif.

Kepercayaan dari pelanggan adalah hal utama, sehingga dalam hal ini pembagian manajemen bandwidth merupakan hal mutlak yang harus dioptimalkan. Hal tersebut tidak lain bertujuan agar pengguna dapat mendapatkan kenyamanan dalam menikmati akses internet yang lancar dan stabil.

Selain pengoptimalan jaringan, maintenance dan monitoring juga merupakan hal yang tidak kalah penting, dalam manajemen bandwidth pemonitoran juga dapat dilakukan melalui traffic bandwidth yang keluar atau telah digunakan user. Semakin banyaknya user maka semakin besar pula Router bekerja untuk melayani client. Beberapa kendala yang terjadi adalah banyak user yang komplain masalah kecepatan akses internet mereka, setiap malam bandwith tidak tertata sesuai yang diinginkan atau sesuai paketan yang dipilih oleh client. Metode HTB dipilih sebagai manajemen bandwidth, router dapat melayani semua user secara merata dan router menjadi optimal [1].

\section{METODE PENELITIAN}

Sebelum penggunaan metode HTB, jaringan yang diamati mengalami traffic yang tidak stabil sehingga client mendapatkan bandwidth yang tidak sesuai. Tes kecepatan menggunakan tool speedtest sebagai acuan utama untuk mengumpulkan data riset. Pada jaringan ini terdapat 8 client aktif dan diambil 2 client sebagai sampel secara acak. Ditemukan bahwa belum ada atau belum diterapkannya metode untuk manajemen bandwidth sehingga diusulkan untuk menerapkan metode HTB guna mempermudah dalam manajemen dan meningkatkan kualitas dari layanan.

Diterapkannya metode HTB untuk mengatur bandwidth yang terdistribusikan ke client. Dalam penerapan suatu metode tentunya harus terlebih dahulu mengetahui bagaimana arsitektur dari jaringan itu sendiri, seperti jumlah user atau jenis layanan yang diberikan. Ketika semua data yang diperlukan sudah terkumpul maka penerapan metode siap untuk dilakukan pada jaringan [1] [2].

Setelah semua diterapkan maka dapat dianalisa hasil yang didapat dengan melalui tes yang dilakukan oleh client dengan menguji kestabilan dan kecepatan yang didapatkan dari tool speedtest.

\section{HASIL DAN PEMBAHASAN}

Alat yang di gunakan berupa:

1. Router adalah sebuah alat yang digunakan untuk berkomunikasi berbeda segmen IP Address yang disebut proses routing. Routing ini terjadi di layer 3 pada 7 layer osi yang berupa Network [3].

2. Mikrotik merupakan sistem operasi yang berfungsi sebagai router pada jaringan. Karena kehandalannya mikrotik mempunyai banyak fitur lengkap pada manajemen bandwidth dan jaringan wireless [4].

3. Winbox adalah sebuah aplikasi yang digunakan sebagai remote access ke mikrotik atau routerboard berbasis GUI dengan port 8291 dan protokol TCP [5] [3]. 
4. Access Point adalah perangkat keras yang memancarkan gelombang radio, access point ini perangkat keras yang menghubungkan client dengan server tanpa kabel, yang memungkinkan lebih hemat biaya dan lebih efisien [5][6].

5. Komputer adalah perangkat keras yang mengelola data sesuai prosedur yang telah ditetapkan oleh pembuat atau pemakai yang bekerja untuk melakukan perhitungan aritmatika [6].

6. ISP (Internet Service Provider) adalah perusahaan yang menyediakan pelayanan supaya kita saling terhubung antar jaringan dengan internet.

7. Latency, merupakan jeda waktu pengiriman paket data dari pengirim ke penerima [7].

8. Bandwidth, merupakan jumlah konsumsi paket data per satuan second atau biasa disebut bit per second [7].

9. Internet adalah jaringan komunikasi yang menghubungkan media elektronik menggunakan protokol TCP/IP sebagai protokol pengirim dan penerima paket [7][8].

10. SpeedTest adalah tool yang digunakan untuk pengujian kecepatan paket yang di transfer.

11. Bandwidth, merupakan jumlah konsumsi paket data per satuan second atau biasa disebut bit per second [7].

Dalam perancangan jaringan dengan menerapkan manajemen bandwidth berdasarkan metode HTB harus memperhatikan banyak hal seperti:

1. Jumlah user

2. Besar bandwidth

3. Kestabilan bandwidth

Tiga hal di atas merupakan item yang sangat berpengaruh dalam hal manajemen bandwidth agar terbagi dengan adil dan rata. Seperti yang terlihat pada Gambar 1 alur kerangka berfikir.

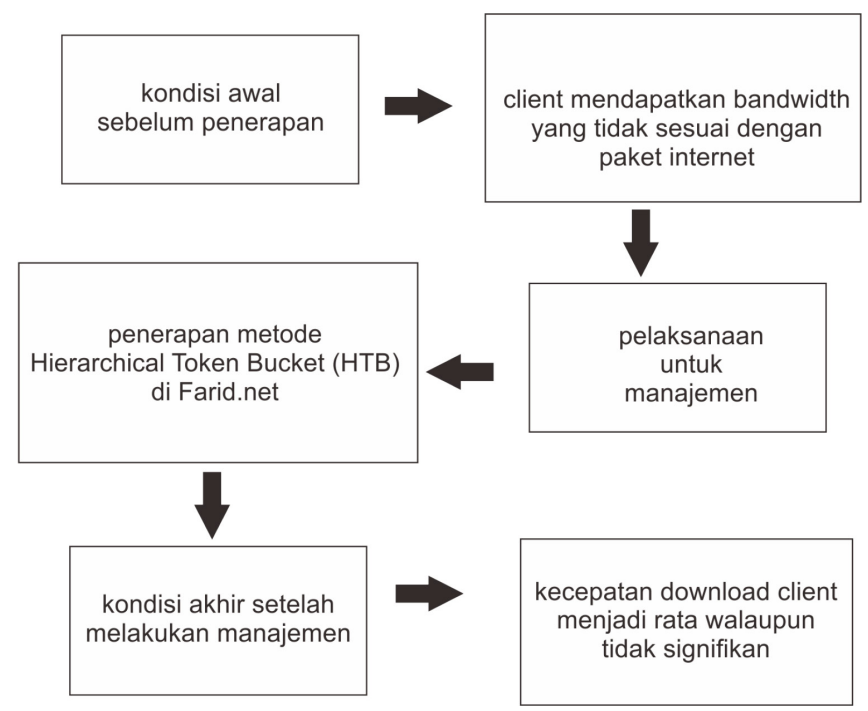

Gambar 1. Kerangka berpikir

Langkah dasar untuk menjalankan metode HTB

1. Melakukan analisa kualitas layanan jaringan, parameter yang diukur pada kualitas layanan jaringan bandwith [8].

2. Pencocokan dan penandaan traffic (mark traffic), selanjutnya mengklasifikasikan traffic untuk penggunaan lebih lanjut, penandaan traffic terdiri dari satu atau lebih parameter pencocokan dalam pemilihan paket dan digunakan untuk kelas - kelas yang spesifik [8] [4].

3. Sebuah aturan dibuat untuk melakukan mark traffic, selanjutnya mark traffic yang telah diberi parameter aturan tersebut digunakan dalam menentukan tindakan (action) yang diambil untuk masing - masing kelas [8] [9]. 
4. Kebijakan diberikan pada interface yang spesifik dan termasuk dalam menambahkan kebijakan untuk semua interfaces (global-in, global-out atau global-total) [10].

\subsection{Konsep Metode HTB}

Dalam metode manajemen bandwidth menggunakan HTB pada dasarnya mempunyai konsep kerja seperti simpan pinjam, metode ini digunakan untuk menjaga kualitas dari sebuah bandwidth yang tersedia kepada semua pengguna yang aktif, dimana bandwidth pada jaringan yang menerapkan metode HTB akan terbagi dalam 2 kelas yaitu [10] [3]: 1) Parent dan 2) Child

Dimana kelas parent akan menjadi kelas utama dengan priority yang paling tinggi dan biasanya mendapat bandwidth paling besar, sementara kelas child berada di bawah kelas parent, hal tersebut tentunya akan berpengaruh dengan besar bandwidth yang didapatkan oleh kelas child [11].

\subsection{Perancangan}

Pada implementasinya, metode HTB dapat diterapkan pada jaringan berskala kecil atau besar, karena kembali pada konsep dasar dari HTB itu sendiri yang bekerja di router sebagai pengatur kendali pembagian bandwidth [10]. Sehingga Metode HTB dipilih untuk digunakan pada Farid.net. Adapun perlengkapan yang diperlukan sebagai berikut:

1. Semua client yang ada di farid.net 8 Client yang aktif

2. 1 routerboard mikrotik RB960PGS

3. 3 kabel utp

4. 1 Access Point

5. Koneksi internet (ISP) sebesar 10Mbps

6. Winbox

\subsubsection{Jenis Layanan paket pada Farid Net}

Pada Farid.Net tersedia jenis paket sebagai berikut:

1. Paket $2 \mathrm{Mbps}$ dengan kecepatan download $2 \mathrm{Mbps}$, Upload $1 \mathrm{Mbps}$, dan jaminan Download 512Kbps dan Upload 256 Kbps dengan harga Rp. 50.000

2. Paket 4 Mbps dengan kecepatan download $4 \mathrm{Mbps}$, Upload $1 \mathrm{Mbps}$, dan jaminan Download 768Kbps dan Upload 256 Kbps dengan harga Rp. 100.000

\subsection{Hasil Percobaan}

Hasil percobaan dari penerapan metode HTB dapat dibuktikan melalui data yang terdapat di queues list. Pada queues list tersimpan track dari traffic penggunaan bandwidth yang berjalan di dalam jaringan, seperti yang terlihat pada Gambar 2. Gambar 3 dan 4 merupakan speed test ketika metode HTB belum diterapkan.

\begin{tabular}{|c|l|l|l|l|l|l|l|l|}
\hline \multicolumn{2}{|l|}{ Queue List } \\
\hline Simple Queues & Interface Queues & Queue Tree & Queue Types \\
\hline
\end{tabular}

Gambar 2. Traffict List Queue sebelum HTB 


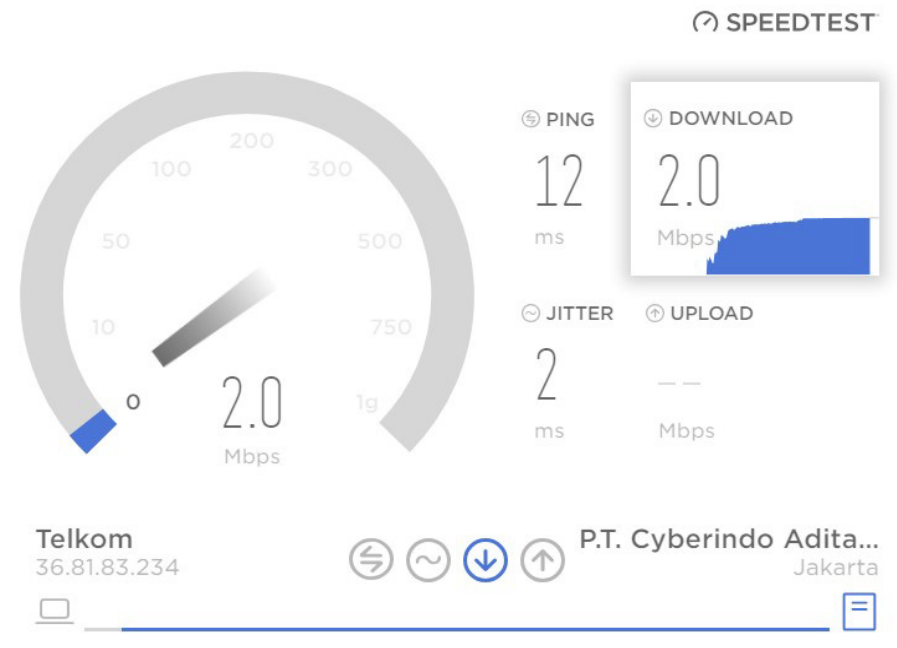

Gambar 3. Speedtest sebelum penerapan HTB Paket 4Mbps

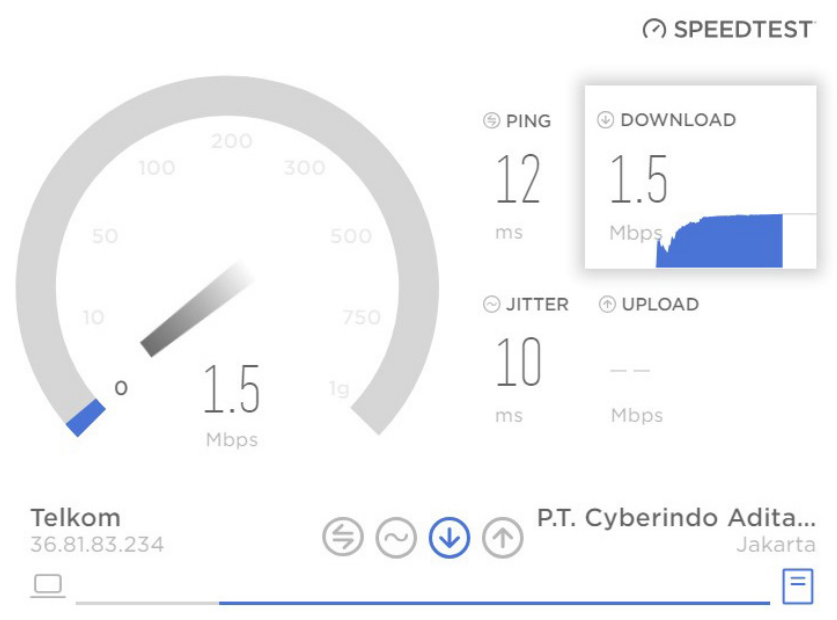

Gambar 4. SpeedTest Sebelum Penerapan HTB paket 2Mbps

Pada paket 4 Mbps terdapat lonjakan yang tinggi sedangkan paket 2Mbps tidak mendapatkan bandwith yang maksimal seperti paket $4 \mathrm{Mbps}$. Pada Gambar 2 traffic di queue list sebelum penerapan metode HTB. Terlihat banyak perbedaan yang diambil oleh client 1 dan 2, Gambar 3 dan Gambar 4. Setelah penerapan HTB terdapat besaran selisih kecepatan download yang hampir merata di setiap usernya. Data tersebut dapat dilihat pada Gambar 5. Pada gambar 6 dan gambar 7 merupakan traffic di queue list setelah menerapkan metode HTB.

\begin{tabular}{|c|c|c|c|c|c|c|c|c|c|c|c|c|c|}
\hline \multicolumn{11}{|c|}{ Queue List } & & \multicolumn{2}{|c|}{$\square x$} \\
\hline \multicolumn{3}{|c|}{ Simple Queues } & \multicolumn{3}{|c|}{ Interface Queues } & Queue Tree & \multicolumn{4}{|c|}{ Queue Types } & & \multirow{2}{*}{\multicolumn{2}{|c|}{ Find }} \\
\hline+ & 口 & $\Leftrightarrow$ & $\$ 3$ & 0 & 8 & o0 Reset C & Counters & & Reset All & Counters & & & \\
\hline$\#$ & & \multicolumn{3}{|l|}{ Name } & \multicolumn{2}{|c|}{ Target } & \multicolumn{2}{|c|}{ Upload Ma } & Downloa... & Upload & Download & & $\nabla$ \\
\hline 8 & & \multicolumn{3}{|c|}{ 马 HTB Total Sem } & \multicolumn{2}{|c|}{$192.168 .10 .0 / 24$} & \multicolumn{2}{|c|}{$3 \mathrm{M}$} & $6 \mathrm{M}$ & $449.0 \mathrm{kbps}$ & $5.6 \mathrm{Mbps}$ & & \\
\hline 2 & & \multicolumn{3}{|c|}{ 色 Newliid Spe } & \multicolumn{2}{|c|}{192.168 .10 .247} & \multicolumn{2}{|l|}{$1 \mathrm{M}$} & $2 \mathrm{M}$ & $0 \mathrm{bps}$ & 206 bps & & \\
\hline 3 & & \multicolumn{3}{|c|}{ 亶 Yudha } & \multicolumn{2}{|c|}{192.168 .10 .248} & \multicolumn{2}{|l|}{$1 \mathrm{M}$} & $2 \mathrm{M}$ & $36.4 \mathrm{kbps}$ & $794.2 \mathrm{kbps}$ & & \\
\hline 4 & & \multicolumn{3}{|c|}{ 量Rumah } & \multicolumn{2}{|c|}{192.168 .10 .249} & \multicolumn{2}{|l|}{$1 \mathrm{M}$} & $4 \mathrm{M}$ & $21.5 \mathrm{kbps}$ & 941.8 kbps & & \\
\hline 1 & & \multicolumn{3}{|c|}{ 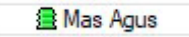 } & \multicolumn{2}{|c|}{192.168 .10 .250} & \multicolumn{2}{|l|}{$1 \mathrm{M}$} & $2 \mathrm{M}$ & $36.9 \mathrm{kbps}$ & $764.0 \mathrm{kbps}$ & & \\
\hline 5 & & \multicolumn{3}{|c|}{ 暳 Upik } & \multicolumn{2}{|c|}{192.168 .10 .251} & \multicolumn{2}{|l|}{$1 \mathrm{M}$} & $4 M$ & $212.4 \mathrm{kbps}$ & $759.3 \mathrm{kbps}$ & & \\
\hline 6 & & \multicolumn{3}{|c|}{ 을 Mbak Yanik } & \multicolumn{2}{|c|}{192.168 .10 .252} & \multicolumn{2}{|l|}{$1 \mathrm{M}$} & $2 \mathrm{M}$ & $29.8 \mathrm{kbps}$ & $396.7 \mathrm{kbps}$ & & \\
\hline 7 & & \multicolumn{3}{|c|}{ 軍 Mas Warto } & \multicolumn{2}{|c|}{192.168 .10 .253} & \multirow{2}{*}{\multicolumn{2}{|c|}{$1 \mathrm{M}$}} & $2 \mathrm{M}$ & $24.6 \mathrm{kbps}$ & $994.6 \mathrm{kbps}$ & & \\
\hline 0 & & \multicolumn{3}{|c|}{ 을 Mas Surat } & \multicolumn{2}{|c|}{192.168 .10 .254} & & & $4 \mathrm{M}$ & $87.2 \mathrm{kbps}$ & $1015.7 \mathrm{kbps}$ & & \\
\hline
\end{tabular}

Gambar 5. Traffic List Queue sesudah HTB 


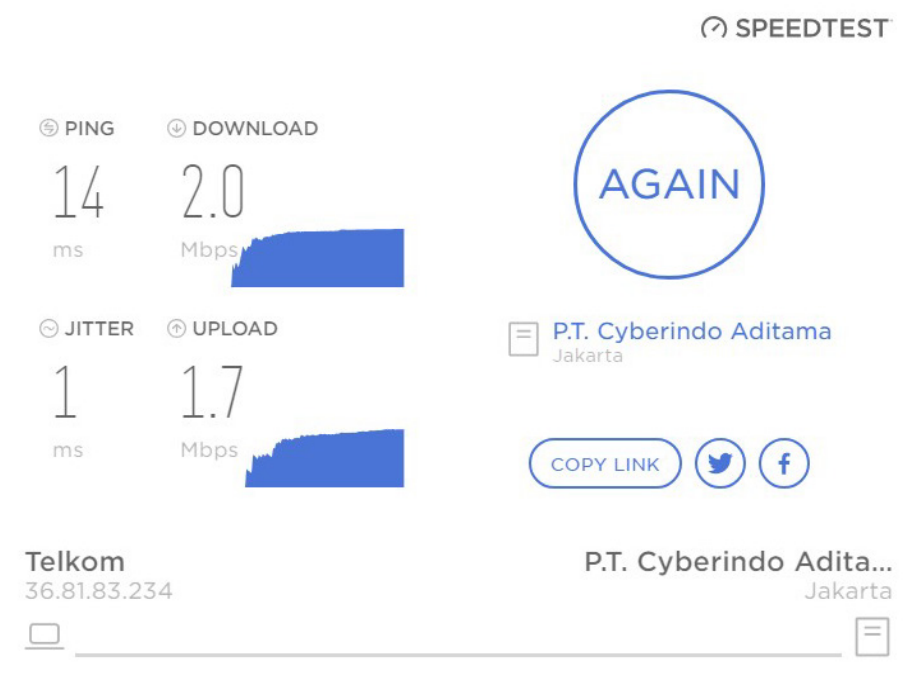

Gambar 6. SpeedTest setelah penerapan HTB paket 2Mbps

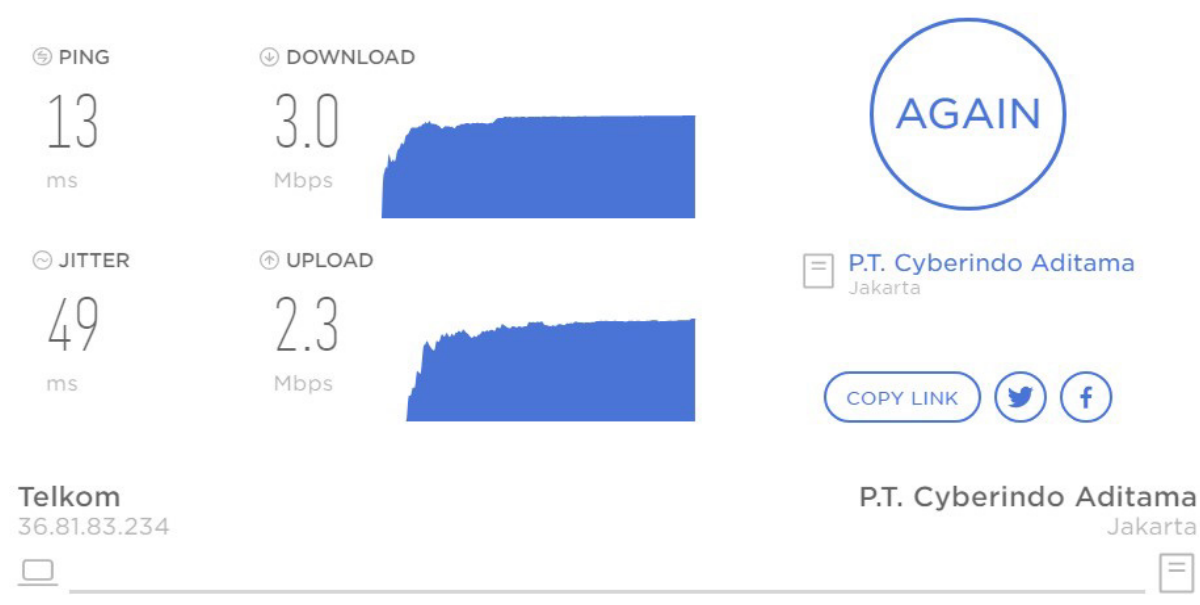

Gambar 7. SpeedTest setelah penerapan HTB Paket 4Mbps

\subsection{Hasil dari Pengamatan}

Dari percobaan diatas didapatkan beberapa data manajemen bandwidth, sehingga dapat disimpulkan bahwa bandwidth dapat terbagi rata di setiap client seperti yang terlihat pada gambar 8. Dengan penjelasan sebagai berikut:

1. Antar pc terdapat selisih sedikit di bandwidth yang disebabkan oleh dialihkannya sisa bandwidth dari setiap client, karena alokasi bandwidth maximum yang bisa didapatkan client tidak lebih dari Maximum Information Rate (MIR) [12].

2. Minimal bandwidth / jaminan bandwidth yang didapatkan oleh client ketika traffic jaringan sedang buruk adalah sebesar $512 \mathrm{kbps}$ dan $768 \mathrm{Kbps}$ sesuai paket yang diambil oleh client, service tersebut biasa disebut dengan Committed Information Rate (CIR), jadi seburuk apapun jaringan maka client tidak akan mendapat bandwidth di bawah CIR [12] [13]. Gambar 9 dan Gambar 10 adalah jaminan bandwith untuk paket 2Mbps dan 4Mbps. 
Citec Journal, Vol. 5, No. 3, Mei 2018 - Juli 2018

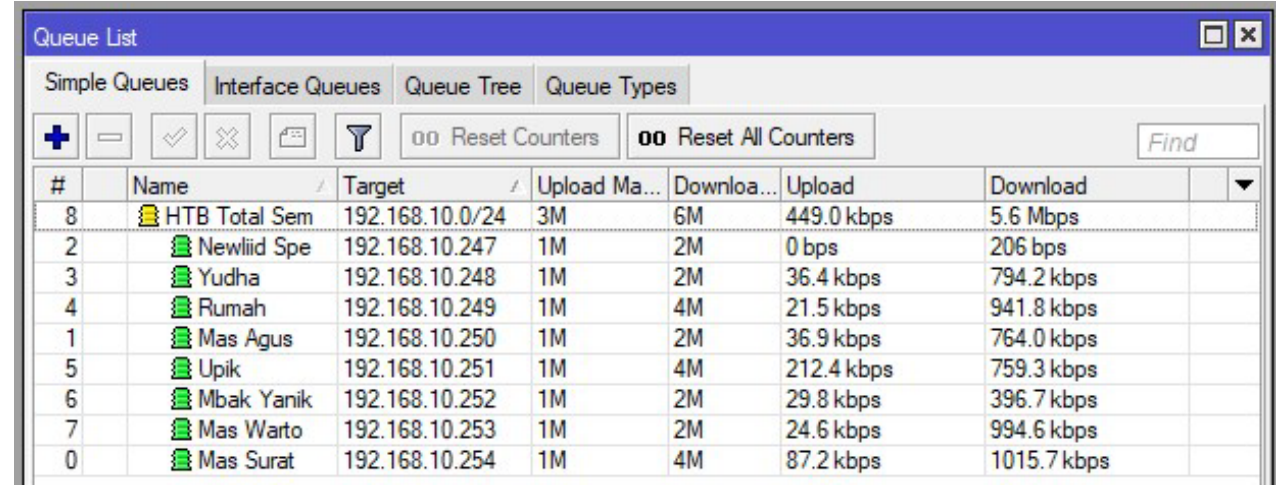

Gambar 8. Traffic Queue Terbagi Rata

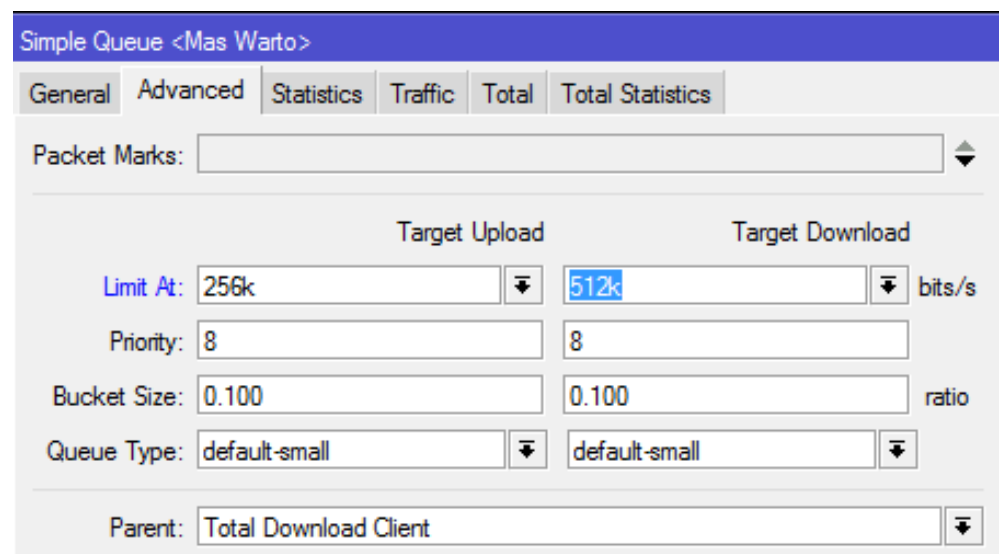

Gambar 9. Jaminan Bandwith paket 2Mbps

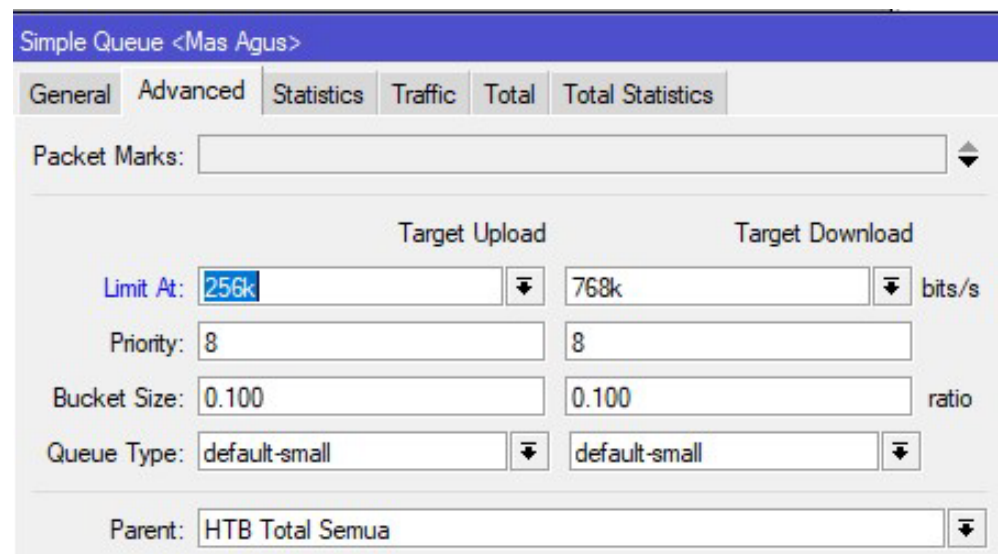

Gambar 10. Jaminan Bandwidth 4Mbps 


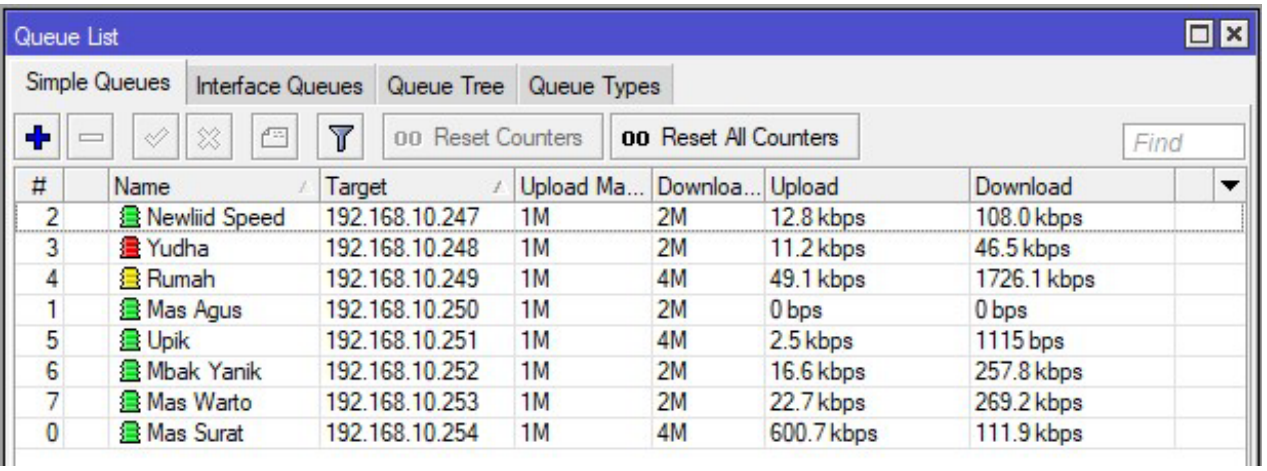

Gambar 11. Traffict Queue Sebelum Penerapan HTB

\begin{tabular}{|c|c|l|l|l|l|l|l||}
\hline \multicolumn{2}{|l||}{ Queue List } \\
\hline Simple Queues & Interface Queues & Queue Tree & Queue Types & \\
\hline
\end{tabular}

Gambar 12. Traffict Queue Sesudah Penerapan HTB

Sebelum penerapan HTB terdapat beberapa client yang status kecepatan internetnya ada yang melonjak dan ada yang tidak mendapatkan bandwith Gambar 11. Pada saat client mendownload paket data seperti digunakan untuk download file maupun digunakan untuk streaming. Client Farid.Net mayoritas internet digunakan untuk mendownload dan streaming. Sebagai network engineer kita diwajibkan untuk memanajemen bandwidth sehingga client dapat terbagi walaupun tidak signifikan Gambar 12.

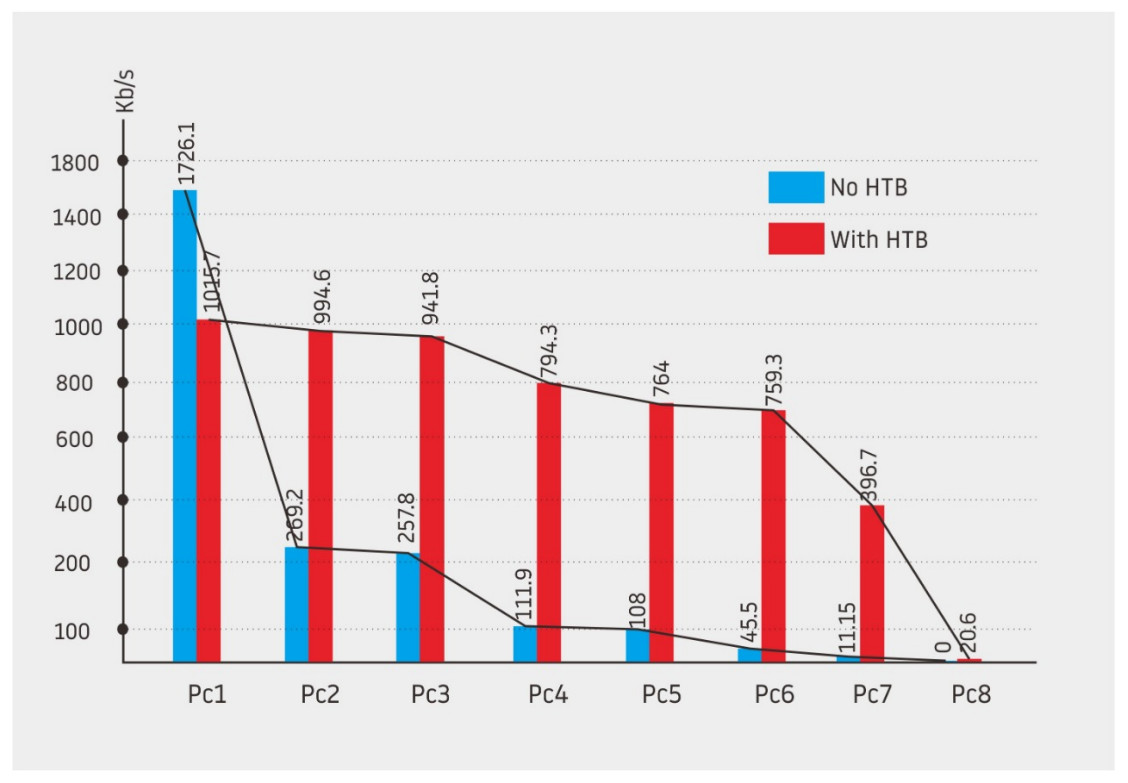

Gambar 13. Grafik Download hasil sesudah dan sebelum penerapan HTB 
Pada Gambar 13 terlihat perbandingan grafik download sebelum dan sesudah penerapan HTB. Data yang dianalisa adalah bandwidth Download, dikarenakan mayoritas client mengunduh paket untuk streaming maupun browsing. Sedangkan user upload tidak terlalu sering digunakan dikarenakan client tidak melakukan upload paket. Jadi dari hasil penelitian diatas dapat disimpulkan bahwa penggunaan metode HTB untuk manajemen bandwidth pada jaringan internet sangat berpengaruh terhadap stabilitas koneksi yang di dapat. Pada traffic di atas garis vertikal merupakan satuan besaran bandwidth sementara garis horizontal merupakan urutan device atau pc. Secara keseluruhan hasil dari penerapan metode HTB sudah disimpulkan dalam satu grafik (Gambar 13), yang mana dalam grafik tersebut warna biru mewakili kondisi ketika jaringan belum diterapkan metode HTB sementara warna merah mewakili kondisi sesudah diterapkannya metode HTB. Pada data grafik tersebut dapat dilihat bahwa kondisi sebelum diterapkannya metode HTB traffic jaringan sangat tidak stabil dan tidak berimbang, hal tersebut terlihat dari tingginya jarak nilai yang tercantum pada warna biru dan pola yang tidak teratur. Berbanding terbalik dengan warna merah yang selisih nilainya cenderung rata dan terpola.

\section{KESIMPULAN}

Kesimpulan dari pembahasan tentang penerapan dan kasus manajemen bandwidth dengan menggunakan metode HTB adalah bahwa penerapan manajemen jaringan khususnya bandwidth merupakan hal yang sangat penting untuk dilakukan, karena bandwidth merupakan salah satu komponen utama. Tanpa adanya manajemen bandwidth yang baik maka bisa dipastikan pelayanan dari jaringan tersebut tidak akan berjalan maksimal.

Dengan menerapkan HTB kondisi traffic jaringan sebelumnya sangat tidak stabil dan tidak berimbang, setelah diterapkan metode HTB

\section{SARAN}

1. Peningkatan jenis layanan dari internet di user sebaiknya ditambah, tidak hanya untuk internet saja mungkin kedepannya bisa di tambahkan dengan iptv ataupun layanan lainya yang dapat menunjang pengoptimalan layanan.

2. Monitoring traffic jaringan sebaiknya dilakukan sebaik mungkin, mengingat kedepannya tidak menutup kemungkinan client akan semakin bertambah.

3. Peningkatan kualitas internet dari ISP dapat ditingkatkan levelnya, hal tersebut beralasan karena semakin kedepannya tuntutan client akan semakin tinggi seiring perkembangan teknologi yang semakin berkembang.

\section{DAFTAR PUSTAKA}

[1] Yunita, P., Irfan, M., Hariyady, 2012, Sistem kontrol server untuk optimasi pembagian bandwidth jaringan menggunakan metode htb (Hierarchical Token Bucket), Jurnal Politala.

[2] Bobanto, W. S., Lumenta, A. S. M., Najoan, X., 2015, Analisis Kualitas Layanan Jaringan Internet (Studi Kasus PT. Kawanua Internetindo Manado), e-journal Teknik Elektro dan Komputer, No. 1, Vo. 4, Hal. 80-87

[3] Gin, Y. G., Oscar, R., 2012, Router Teknologi, Konsep, Konfigurasi, dan Troubleshooting Berbasis Windows, Cisco, MacOS, Linux \& Microtik Router, Informatika, Bandung.

[4] Syafrizal, M., 2005, Pengantar Jaringan Komputer, Andi Publisher, Yogyakarta.

[5] Herlambang, M. L., Laksono, C. A., 2008, Panduan Lengkap Menguasai Router Masa Depan Menggunakan Mikrotik RouterOS, Andi Publisher, Yogyakarta. 
[6] Sofana, I., 2008, Membangun Jaringan Komputer, Informatika, Bandung.

[7] Riadi, I., Wicaksono, W. P., Implementasi Quality of Service Menggunakan Metode Hierarchial Token Bucket, Jurnal Sistem Informasi Indonesia (JUSI), No.2, Vol. 1, Hal. 93 103

[8] Rendra, T., 2013, MikroTik Kung Fu (Kitab 1), Penerbit Jasakom, Jakarta.

[9] Lisnawita, 2016, Manajemen Bandwidth menggunakan metode Hierarchical Token Bucket, Jurnal Teknologi Informasi \& Komunikasi Digital Zone, NO. 1, Vol. 7, Hal. 18-25.

[10] Wijaya, A. I., Handoko, L. B., 2013, Menejemen Bandwidth dengan Metode HTB (Hierarchical Token Bucket) pada Sekolah Menengah Pertama Negeri 5 Semarang, Skripsi, Teknik Informatika, Fakultas Ilmu Komputer, Univ. Dian Nuswantoro, Semarang.

[11] Arifin, Y., 2012, Implementasi Quality Of Service Dengan Metode Htb (Hierarchical Token Bucket) Pada PT.Komunika Lima Duabelas, Jurnal Elektro Ilmu Komunikasi, No. 2, Vol. 1, Hal. 1-7

[12] Kencana P, S., Mutiara, G. A., Iskandar, M. I., 2012, Implementasi Algoritma Per Connection Queue (PCQ) Dalam Algoritma Hierarchical Token Bucket (HTB) Untuk Pembagian Bandwidth Pada Warnet Khelambiqunet, Skripsi, Teknik Komputer, Politeknik Telkom Bandung.

[13] Prayoga, S., 2013, Implementasi Pengaturan dan Prioritas Bandwidth dengan Hierarchical Token Bucket berbasiskan GUI pada Linux Server Clearos, Jurnal Teknik Komputer UNIKOM Komputika, No. 1, Vol. 2, Hal. 22-28 